\title{
Do Monetary Policy Transparency, Independence and Credibility Enhance Macro-Financial Stability?
}

\author{
Eleftherios SPYROMITROS \\ University of Strasbourg, BETA \\ 61 avenue de la Fôret Noire, 67000 STRASBOURG \\ E-mail: spyro@unistra.fr \\ Sukriye TUYSUZ (Corresponding author) \\ University of Strasbourg, BETA \\ 61 avenue de la Fôret Noire, 67000 STRASBOURG \\ E-mail: skr.tuysuz@gmail.com \\ Accepted: March 2, 2012 \\ Published: April 1, 2012 \\ URL: http://dx.doi.org/10.5539/ijef.v4n4p44
}

Received: January 2, 2012

doi:10.5539/ijef.v4n4p44

\begin{abstract}
This paper, using panel data approach, evaluates the effect of, respectively, the central bank transparency, independence and credibility on, respectively, the level and variability of realized and expected economic performance. It also analyzes the effects of central banks characteristics on the level and variability of Government bond rate. The results obtained suggest that central bank independence does not influence the realized and expected level and variability of economic performance. As for the central bank transparency, our findings are consistent with the view that greater transparency could have a desirable reputational effect that lowers inflation expectations and long-term nominal interest rates. Finally, our results show that central bank credibility negatively influences the level and variability of Government bond rate.
\end{abstract}

Keywords: Central bank transparency, Credibility, Independence, Financial market, Macroeconomics variables

\section{Introduction}

The role of central bank credibility $(\mathrm{CBC})$ is of great importance in order to improve macroeconomic and financial outcomes. On the one hand, it leads to price stability by anchoring private sector inflationary expectations and is also associated with sustainable growth (Cechetti and Krause, 2002). On the other hand, by lessening monetary policy uncertainty, it induces a smaller variability of financial assets since the anchoring of inflation expectations will lead to a reduction in the level of the interest rates (Fisher hypothesis). However, the conduct of monetary policy is made in face of tremendous uncertainty concerning the economy as a whole (supply or demand shocks). Kydland and Prescott (1977) showed that only an unanticipated monetary policy could affect macroeconomic variables in an environment where economic agents form their anticipations rationally. In this respect, Barro and Gordon (1983) demonstrated that there is always a trade-off between credibility and flexibility. Indeed, the difference between output stabilization and price stability can be viewed as the main difference between discretion and rules.

In fact, monetary policy rules seem to be optimal in terms of credibility but they lack of flexibility. Therefore, the time consistent monetary policy is the one conducted in a discretionary manner, but it evolves an inflationary bias. Rogoff (1985) proposed to delegate the monetary policy to conservative and independent central banks in order to gain in credibility and be able to reduce the created bias. Both theoretical and empirical researches identify central bank independence (CBI) as the institutional device associated with lower inflation and no less growth (Note 1). Indeed, CBI is instituted in most of the central banks but raises the question whether it is democratic or not to consider unelected officials in the conduct of monetary policy (Stiglitz, 1998). Hence, the role of central bank transparency (CBT) appears to be crucial because it renders central bankers accountable but also more credible in the eyes of the public. According to Cukierman (2001), Faust and Svensson (2001), and Geraats et al., (2006), the advantages of greater transparency on the credibility, as well as reputation and flexibility, derive from the fact that transparency makes it easier for the private sector to infer the central bank's intentions regarding monetary policy 
decisions, improving though central bank's credibility. Central bank incentives to build reputation increase as private sector inflation expectations become more sensitive to monetary policy actions and outcomes that are not associated with economic shocks. Simultaneously, central bank flexibility is enhanced by the fact that monetary policy decisions that are intended to offset economic shocks are transparent, leading to a better stabilization of the economy without affecting private sector inflation expectations. Those advantages of transparency should able to deliver better overall policy outcomes, reduce uncertainty related to the monetary policy, decrease the heterogeneity in agents expectations and lower the risk premium related to future inflation and the interest rates level (Geraats et al., 2006).

In the empirical literature, a large strand of empirical research is focused on the effects of CBC, CBT and $\mathrm{CBI}$ on the macroeconomic variables of inflation and output growth (level and variability). Several empirical studies including Alesina (1988; 1989), Grilli et al., (1991), Cukierman et al., (1992), Ismihan and Ozkan (2004) and Brumm (2006) find that CBI is associated with lower levels of inflation (Note 2). In contrast to the early empirical studies, Cecchetti and Krause (2002) find no influence of CBI on the level and variability of inflation. Concerning the effects of independence on output, Alesina and Summers (1993) and Cecchetti and Krause (2002) find no relation between the variability of output growth and the CBI. As for the effect of CBT, several papers highlight empirically the beneficial effect of higher transparency at the level of inflation (Kuttner and Posen, 1999, Chortareas et al., 2002; Sterne et al., 2002; Siklos, 2003; Fatas et al., 2006, Demertzis and Hughes Hallett, 2007; Dincer and Eichengreen, 2007).

These studies do not consider the effect of central bank characteristic on the private sector expectations. This latter effect are considered by few authors, such as Corbo et al., (2001), Johnson (2002), Gulkaynak et al., (2005) and Crowe (2006). All these authors analyze the effect of a greater transparency, implied by the adoption of Inflation-Targeting, on the expected inflation. The findings of these studies are ambiguous. Indeed, Crowe find that better public information is most beneficial for forecasters with bas private information, whereas Johnson find that neither the forecasts variability nor their absolute errors are reduced by Inflation-Targeting. As for Corbo et al., they find a fall in forecast errors among countries that adopt Inflation-Targeting, although the fall seems to precede the adoption of Inflation-Targeting in many cases.

As we can notice, authors, cited in the previous paragraph, analyze only the effect of a greater transparency, implied by the adoption of Inflation-Targeting, on the expectation of inflation. A greater transparency implied by all other measures could also affect the expectation of agents as well as a greater credibility or independence can also influence the expectation of agents. In this context, we contribute to literature by taking into account the effect of $\mathrm{CBC}, \mathrm{CBT}$ and $\mathrm{CBI}$ on expected inflation and output, respectively.

Our second implication rests on the effects of central bank characteristics on the financial market. Alesina and Summers (1993) argue that interest rate variability is decreasing with higher CBI, suggesting that more credible central banks benefit from less variable interest rates. As for the effects of CBT, there is only few studies examining empirically the direct effects of CBT on financial market. Siklos (2004) notices that nominal interest rates are lower for countries with a clear inflation objective. As for Geraats et al., (2006), analyzing the effects of various transparency changes, they found that greater transparency have had a significant beneficial effect on the level of interest rates. As we notice, these studies are very limited compared to our objectives, which consist to analyze the effects of $\mathrm{CBI}, \mathrm{CBC}$ and $\mathrm{CBT}$ on the level and the variability of interest rates.

Finally, many of the existing empirical studies are based on very limited country samples (see for example Eijffinger and Geraats, 2006 and Demertzis and Hallett, 2007) or utilize evidence for a single point in time (see for example Cecchetti and Krause, 2002). However, cross-section approach presents several disadvantages. Cross-section analysis does not permit the inclusion of country fixed effects. In contrast, transparency and economic outcomes may be picking up the effects of other country characteristics that are difficult to detect. In addition, a cross-section approach does not take into account the meaningful temporal variation in existing measures of CBI, CBT and CBC and in other variables retained in the estimation. During the early nineties some economies experienced dramatic changes in CBI and CBT (Note 3).

In order to take into account the country specific effects and the meaningful temporal variation in dependent and explanatory variables, we use panel data approach. That way we evaluate the effect of CBT, CBI and CBC on the level \& the variability of realized and expected economic performance (inflation rate and gross domestic product rate). Furthermore, we analyze also the effects of central banks characteristics on the level and variability of Government bond rates. In particular, we analyze the relation between financial \& macroeconomic variables and $\mathrm{CBI}, \mathrm{CBT}$ and $\mathrm{CBC}$ for a long period. 
This paper is structured as follows: Section 2 describes the data and the methodology used in our analysis. In Section 3, we present and discuss the results and section 4 concludes.

\section{Data and Methodology}

This paper investigates the relation between financial \& macroeconomic variables and CBI \& CBC, respectively, for the period 1991-1998. We also analyze the relation between these macroeconomic \& financial variables and the CBT for the period 1999-2005. For each analysis, we consider about 20 OCDE countries (Note 4).

\subsection{Data}

\subsubsection{Central Bank Independence, Transparency and Credibility Index}

Several methods (Note 5) to construct the index of CBI are proposed in the literature. The most widely employed index is due to Cukierman et al., (1992). Based on this method, Polillo and Guillén (2005) construct an index of independence for a large sample of countries (92 countries) and for a longer period of time (1989-2000). Accordingly, we use their index in our analysis.

In the same way, in the literature, several CBT indexes are proposed (Fry et al., 2000; Mahadeva and Sterne, 2000, Bini-Smaghi and Gros, 2001; Siklos, 2002; De Haan et al., 2004; Eijffinger and Geraats, 2006; Dincer and Eichengreen, 2007). These authors construct the index either for a very limited number of central banks or a single point in time, in the exception of Dincer and Eichengreen. These authors construct an index for a large range of central banks (124) and a long period (1998-2005) (Note 6). Their index is more suitable for cross section time series analysis, and therefore we retain it in our analysis.

Finally, concerning the credibility index in the literature the most frequently used method is this proposed by Cukierman and Meltzer (Note 7) (1986). This methodology defines CBC as "the absolute value of the difference between the policymaker's plans and the public's beliefs about those plans". We use this methodology, described in appendix, to determine the $\mathrm{CBC}$.

\subsubsection{Macroeconomic and Financial Variables}

Concerning the financial data, we use the level and variation of 5-year \& 10-year government bond rates, respectively. As for the macroeconomic variables, we retain the expected \& realized inflation and the expected \& realized gross domestic product (GDP) growth. All data are annual and extracted from Datastream.

\subsection{Model}

In order to take into account the country specific effects, the meaningful temporal variation in $\mathrm{CBI}, \mathrm{CBT}$ and $\mathrm{CBC}$ index, we use panel data approach to evaluate the effects of the CBT, CBI and CBC respectively on the macroeconomic and financial variables respectively. In this model, the dependent variable $(y)$ can be expressed as:

$$
y_{j, n, t}=a_{i, j, n, t}+b_{i, j} \cdot x_{i, n, t-1}+\varepsilon_{i, j, n, t}, \quad n=1, \ldots, N ; t=1, \ldots, T
$$

Where $x_{i}$ denotes explanatory variables that are independent of the error of the equation, $\varepsilon_{i t}$. This explanatory variable represents the $\mathrm{CBI}, \mathrm{CBT}$ and $\mathrm{CBC}$ index, respectively. As for the dependent variables $\left(y_{j}\right)$, they correspond to the expected inflation, realized inflation, expected GDP growth, realized GDP growth, 10-year bond rate level, 10-year bond rate variation, 5-year bond rate level and 5-years rate variation. The regressions are implemented in univariate terms in order to examine the effect of the index in question on the moment of a given macroeconomic and financial variable. For instance, we regress the transparency index $\left(x_{i}\right)$ on the 10-year bond rate variation $\left(y_{j}\right)$.

In order to take into account the country specific effect, we use "fixed effects" and "random effects" models. Hausman (1978) test enables us to choose between the "fixed effects" and the "random effects" model.

\section{Results}

We now present and discuss our results.

\subsection{The Effects of Central Bank Independence (CBI)}

The results in table 1 indicate a negative but statistically not significant relation between the CBI and the level of realized and expected inflation respectively. Our findings are in line with results obtained by Cecchetti and Krause (2002) and Ismahan and Ozkan (2005). Similarly, we find that the variability of inflation and inflation expectations is not affected by CBI. The above results do not confirm previous theoretical suggestions (Rogoff, 1985) and are also in contrast with empirical results obtained by several authors, as Grilli et al., (1991), Cukierman et al., (1992), Alesina and Summers (1993) and Brumm (2006). Moreover, table 1 shows that the CBI does not influence the level of expected \& realized GDP growth, and the level \& variability of GDP growth respectively. This result is also not 
consistent with theory (Rogoff, 1985). However, our observations are in line with results obtained by some authors, as Alesina and Summers (1993) and Cecchetti and Krause (2002). Finally, table 1 suggests that CBI negatively affects the level and variability of both interest rates. The negative effect on the variability of the interest rate can be explained by the reduction of uncertainty related to monetary policy. As for the reduction of the bond rate level, it is obtained through the anchoring of expected long-term inflation.

\subsection{The Effects of Central Bank Transparency (CBT)}

Our results show that $\mathrm{CBT}$ reduces the level of realized inflation \& inflation expectations, but has no influence on inflation variability. These findings are consistent with recent empirically literature (Chortareas et al., 2002; Mishkin, 2004).

More information about monetary policy is not associated with sustainable growth (Table 2). Indeed, our results show that CBT negatively influences the level of economic growth and the expected economic growth respectively. We observe that our findings are not in line with previous empirical and theoretical studies on this subject (see for instance Demertzis and Hallett, 2007). Concerning now the variability of realized \& expected economic growth; we notice that CBT has no implications for both variables. These observations confirm the previous empirical results (Sterne et al., 2002, Fatas et al., 2006; Demertzis and Hallett, 2007) but not the theoretical propositions of Demertzis and Hallett (2007). This latter proposition suggests that a more transparent monetary policy may be associated with more output volatility because it prevents the authorities from using policy actively to offset output fluctuations.

Finally, table 2 suggests that CBT is negatively related to 5 year and 10 year bond rate level, respectively. The results concerning the level of interest rates are in accordance with theoretical and empirical results obtained by Geraats et al., (2006). In fact, our findings are consistent with the view that greater transparency could have a desirable reputational effect that lowers inflation expectations and long-term nominal interest rates.

\subsection{The Effects of Central Bank Credibility (CBC)}

In order to provide a stable environment for financial market, that facilitates the task to the central bank in reaching its target, central banks seek to reduce the interest rate variability (Goodfriend, 1990; Froyen and Waud, 1995; Goodhard, 1996; Woodford, 1999). To reduce the financial instability, central banks started to enhance their credibility (Faust and Svensson, 2001). Greater credibility of central bank leads to the reduction of financial speculation and reduces the heterogeneity of markets operators' expectations about the future monetary authorities' decisions. Thus, greater credibility increases the predictability of central bank decisions and reduces the level of the interest rate and financial market volatility. Results in table 3 confirm the expected impacts of $\mathrm{CBC}$ on the financial market. Indeed, according to these results, $\mathrm{CBC}$ negatively influences the level \& variability of bond rates.

Our results also show a negative relation between $\mathrm{CBC}$ and observed \& expected inflation level. Greater $\mathrm{CBC}$ should improve macroeconomic outcomes. Particularly, $\mathrm{CBC}$ leads to price stability by anchoring private agents inflationary expectations (Cecchetti and Krause, 2002). Moreover, we find evidence suggesting an increase in the variability of realized \& expected inflation. Finally, we find a negative impact of credibility on realized economic growth.

\section{Conclusion}

The conduct of monetary policy has moved during the past decade to a new paradigm which gives accent to central bank's credibility, independence and transparency. It is generally agreed that the above changes in the central bank's operational framework have produced better overall policy outcomes. In this paper, we investigate the empirical relationships between economic and financial performance, and the central bank characteristics described above.

We find that central bank independence has a negative affect on the level and the variability of both interest rates. Our results do not show statistically significant relations between central bank independence and all the other dependent variables. Considering the effects of central bank transparency on macro-financial variables, our results show that central bank transparency reduces the level of inflation and inflation expectations as well as the level of realized economic growth. We also suggest that central bank transparency is negatively related to 5-year and 10 -year bond rate level, respectively. Finally, regarding the effects of credibility on macroeconomic and financial performance, we observe that central bank credibility negatively influences the level and variability of bond rates as well as the level of inflation and inflation expectations.

\section{References}

Alesina, A. (1988). Macroeconomics and politics. NBER Macroeconomics Annual. Cambridge. MIT Press, 13-62.

Alesina, A. (1989). Politics and business cycles in industrial democracies. Economic Policy, 4(8), 55-98. http://dx.doi.org/10.2307/1344464 
Alesina, A., \& Summers, L. (1993). Central bank independence and macroeconomic performance. Journal of Money, Credit, and Banking, 25, 157-162. http://dx.doi.org/10.2307/2077833

Barro, R., \& Gordon, D. (1983). A positive theory of monetary policy in a natural rate model. Journal of Political Economy, 91, 589-610. http://dx.doi.org/10.1086/261167

Beetsma, R. M., \& Jensen, H. (2003). Why money talks and wealth whispers: Monetary uncertainty and mystique: Comment. Journal of Money, Credit and Banking, 35(1), 129-136. http://dx.doi.org/10.1353/mcb.2003.0001

Bini-Smaghi, \& Gros, D. (2001). Is the ECB sufficiently accountable and transparent?. ENEPRI Working Paper, No 7. http://aei.pitt.edu/1861/1/ENEPRI_WP07.pdf

Blinder, A. S. (2000). Central bank credibility: why do we care? How do we build it?. The American Economic Review, 90, 1421-1431. http://dx.doi.org/10.1257/aer.90.5.1421

Bomfim, A., \& Rudebusch, G. (2000). Opportunistic and deliberate disinflation under imperfect Credibility. Journal of Money Credit and Banking, 32, 707-721. http://dx.doi.org/10.2307/2601179

Brumm, H. J. (2006). The effect of central bank independence on inflation in developing countries. Economics Letters, 90(2), 189-193. http://dx.doi.org/10.1016/j.econlet.2005.07.025

Cecchetti, S., \& Krause, S. (2002). Central bank structure, policy efficiency and macroeconomic performance: Exploring the empirical relationships. The Federal Reserve Bank of St. Louis Review, 84(4), 47-60. http://research.stlouisfed.org/publications/review/article/2331

Chortareas, G., Stasavage, D., \& Sterne, G. (2002). Monetary policy transparency, inflation and the sacrifice ratio. International Journal of Finance and Economics, 7(2), 141-155. http://dx.doi.org/10.1002/ijfe.183

Chortareas, G., Stasavage, D., \& Sterne, G. (2003). Does monetary policy transparency reduce disinflation costs?. The Manchester School, 71(5), 21-540. http://dx.doi.org/10.1111/1467-9957.00365

Clare, A., \& Courtenay, R. (2001a). Assessing the impact of macroeconomics news announcements on securities prices under different monetary policy regimes. Bank of England Working Paper, No 125. http://www.bankofengland.co.uk/publications/workingpapers/wp125.pdf

Clare, A., \& Courtenay, R. (2001b). What can we learn about monetary policy transparency from financial market data?. Deutsche Bundesbank Discussion Paper, $\quad$ No http://www.olsen.ch/fileadmin/Publications/Client_Papers/200102-ClareCourtenay-WhatLearnMonetaryPolTranspa rencyFinMkts.pdf

Crosby, M. (1998). Central bank independence and output variability. Economics Letters, 60, 67-75. http://dx.doi.org/10.1016/S0165-1765(98)00073-1

Crowe, C. (2006). Testing Transparency Benefits of Inflation Targeting: Evidence from Private Sector Forecasts. IMF Working Paper, No WP/06/289. http://www.imf.org/external/pubs/ft/wp/2006/wp06289.pdf

Corbo, V., Landerretche, O., \& Schmidt-Hebbel, K. (2001). Assessing Inflation Targeting after a Decade of World Experience. International Journal of Finance and Economics, 6 (4), pp. 343-368.http://dx.doi.org/10.1002/ijfe.165

Cukierman, A. (1998). The economics of central banking. In H. C. Well (ed.), Contemporary Policy issues: Macroeconomics and Finance, Macmillan Press in association with the International Economic Association.

Cukierman, A. (2001). Accountability, credibility, transparency and stabilization policy in the eurosystem. In Charles Wyplosz ed., The impact of EMU on Europe and the developing Countries, Oxford University Press chap. 3 , 40-75.

Cukierman, A. (2002). Are contemporary central banks transparent about economic models and objectives and what difference does it make?. The Federal Reserve Bank of St. Louis Review, 84(4), 15-36. http://research.stlouisfed.org/publications/review/article/2330

Cukierman, A., \& Meltzer, A. (1986). The theory of ambiguity, credibility, and inflation under discretion and asymmetric information. Econometrica, 54, 1099-1128. http://dx.doi.org/10.2307/1912324

Cukierman, A., Miller, G. P., \& Neyapti, B. (1998). Central bank reform, liberalization and inflation in transition economies - an international perspective. Manuscript, July.

Cukierman, A., Webb, S. B., \& Neyapti, B. (1992). Measuring the independence of central banks and its effects on policy outcomes. The World Bank Economic Review, 6, 353-398. http://dx.doi.org/10.1093/wber/6.3.353 
De Haan, J., Leertouwern, E., Meijer, E., \& Wansbeek, T. (2003). Measuring central bank independence: A latent variables approach. Scottish Journal of Political Economy, 50(3), 326-340. http://dx.doi.org/10.1111/1467-9485.5003005

De Haan, J. (1997). The European central bank: Independence, accountability and strategy: A review. Public Choice, 93, 395-426. http://dx.doi.org/10.1023/A:1004972705141

De Haan, J., Amtenbrink, F., \& Waller, S. (2004). The transparency and credibility of the European central bank. Journal of Common Market Studies, 42(4), 775-794.

Demertzis, M., \& Hughes Hallett, A. (2007). Central bank transparency in theory and practice. Journal of Macroeconomics, 29(4), 760-789. http://dx.doi.org/10.1016/j.jmacro.2005.06.002

Demiralp, S. (2001). Monetary policy in a changing world: Rising role of expectations and the anticipation effect. Board of Governors of the Federal Reserve System. Finance and Economics Discussion Series, 2001-55. http://www.federalreserve.gov/pubs/feds/2001/200155/200155abs.html

Dincer, N. N., \& Eichengreen, B. (2007). Central bank transparency: Where, why, and with what effects?. NBER Working Paper, No 13003. http://www.nber.org/papers/w13003.pdf

Eijffinger, S. C. W., \& de Haan, J. (1996). The political economy of central bank independence. Princeton Studies in International Economics, 19, International Economics Section, Department of Economics Princeton University.

Eijffinger, S. C. W., Geraats, P. M. (2006). How transparent are central banks?. European Journal of Political Economy, 22(1), 1-21. http://dx.doi.org/10.1016/j.ejpoleco.2005.09.013

Eijffinger, S. C. W., Hoeberichts, M., \& Schaling, E. (2000). Why money talks and wealth whispers: Monetary uncertainty and mystique. Journal of Money, Credit and Banking, 32(2), 218-235. http://dx.doi.org/10.2307/2601240

Eijffinger, S. C. W., Hoeberichts, M., \& Schaling, E. (2003). Why money talks and wealth whispers: Monetary uncertainty and mystique: Reply. Journal of Money, Credit and Banking, 35(1), 137-139. http://dx.doi.org/10.1353/mcb.2003.0006

Eijffinger, S., \& Tesfaselassie, M. F. (2007). Central bank forecasts and disclosure Policy: Why it pays to be optimistic. European Journal of Political Economy, 23(1), 30-50. http://dx.doi.org/10.1016/j.ejpoleco.2006.09.008

Fatas, A., Mihov, I., \& Rose, A. K. (2006). Quantitative goals for monetary policy.'ECB Working Paper Series No 615. http://www.ecb.int/pub/pdf/scpwps/ecbwp615.pdf

Faust, J., \& Svensson, L. E. O. (2001). Transparency and credibility: monetary policy with unobservable goals. International Economic Review, 42(2), 69-397. http://dx.doi.org/10.1111/1468-2354.00114

Faust, J., \& Svensson, L. E. O. (2002). The equilibrium degree of transparency and control inmonetary policy. Journal of Money, Credit and Banking, 34(2). http://dx.doi.org/10.1353/mcb.2002.0037

Fisher, I. (1930). The theory of interest rate. Macmillan. New York.

Fracasso, A., Genberg, H., \& Wyplosz, C. (2003). How do central banks write? An evaluation of inflation targeting central banks. Special Report 2 of Geneva Reports on the World Economy, Centre for Economic Policy Research. http://www.norges-bank.no/upload/import/konferanser/2003-05-05/data/fracasso.pdf

Froyen, R., \& Waud, R. (1995). Central bank independence and the output inflation trade-off. Journal of Economics and Business, 47, 137-149. http://dx.doi.org/10.1016/0148-6195(94)00042-C

Fry, M., Julius, D., Mahadeva, L., Roger, S., \& Sterne, G. (2000). Key issues in the choice of a monetary policy framework. in L. Mahadeva and G. Sterne (eds), Monetary Policy Frameworks in a Global Context, London: Routledge, 1-216.

Fujiwara, I. (2005). Is the central bank's publication of economic forecasts influential?. Economics Letters, 89, 255-261. http://dx.doi.org/10.1016/j.econlet.2005.05.036

Garfinkel, M. R., \& Oh, S. (1995). When and how much to talk credibility and flexibility in monetary policy with private information. Journal of Monetary Economics, 35, 341-357. http://dx.doi.org/10.1016/0304-3932(95)01193-R

Geraats, M. P. (2002). Central bank transparency. Economic Journal, 112, 532-565. http://dx.doi.org/10.1111/1468-0297.00082 
Geraats, M. P. (2005). Transparency and reputation: The publication of central banks forecasts. Topics in Macroeconomics, 5(1), 1-26.

Geraats, P. M., Eijffinger, S. C. W., \& van der Cruijsen, C. A. (2006). Does central bank transparency reduce interest rates?. CEPR Discussion Papers, No 5526.

Gerlach-Kristen, P. (2004). Is the impacts voting record informative about future UK monetary policy? Scandinavian Journal of Economics, 106(2), 299-313. http://dx.doi.org/10.1111/j.0347-0520.2004.00359.x

Gersbach, H. (2003). On the negative social value of central banks' knowledge transparency. Economics of Governance, 4(2), 91-103.

Gurkaynak, R., Levin, A., \& Swanson, E., H. (2005). Does Inflation Targeting Anchor Long-Run Inflation Expectations? Evidence from Long-Term Bond Yields in the U.S., U.K., and Sweden. Mimeo.

Goodfriend, M. (1990). Interest rates and the conduct of monetary policy. Working Paper of Federal Reserve Bank of Richmond, No 90-06. http://www.richmondfed.org/publications/research/working_papers/1990/pdf/wp90-6.pdf.

Goodhart, C. (1996). Why do the monetary authorities smooth interest rates?. LSE Financial Markets Group Special Paper, No 81.

Grilli, V., Masciandaro, D., \& Tabellini, G. (1991). Political and monetary institutions and public finance policies in the industrialized countries. Economic Policy, 13, 341-392.

Hausman, J. (1978). Specification and estimation of simultaneous equations models. In Z. Griliches, and M. Intriligator, (eds.), Handbook of Econometrics, Amsterdam: North Holland.

Hoeberichts, M., Tesfaselassie, M., \& Eijffinger, S. (2004). Central bank communication and output stabilization.' Netherlands Central Bank

http://www.dnb.nl/binaries/Working\%20Paper\%203_tcm46-146660.pdf

Discussion

papers.

Hutchison, M., \& Walsh, C. (1998). The output-inflation trade-off and central bank reform: evidence from New Zealand. Economic Journal, 108, 703-725. http://dx.doi.org/10.2307/1344630

Ismihan, M., \& Ozkan, F. G. (2004). Does central bank independence lower inflation?. Economics Letters, 84(3), 305-309. http://dx.doi.org/10.1016/j.econlet.2003.12.022

Issing, O. (1999). The eurosystem: Transparent and accountable or Willem in Euroland. Journal of Common Market Studies, 37(3), 503-519.

Johnson, D. (2002). The Effect of Inflation Targeting on the Behavior of Expected Inflation: Evidence from an 11 Country Panel, Journal of Monetary Economics, Vol. 49, 1521-38. http://dx.doi.org/10.1016/S0304-3932(02)00181-2

Kissmer, F., \& Wagner, H. (1998). Central bank independence and macroeconomic performance: a survey of the evidence. in: N. Healey and P. Levine (eds.), Central Banking in Eastern Europe, London: Routledge.

Kohn, D. L., \& Sack, B. P. (2003). Central bank talk: Does it matter and why?. Board of Governors of the Federal Reserve System, (U.S.), Finance and Economics Discussion Series, 2003-55. http://www.federalreserve.gov/pubs/feds/2003/200355/200355pap.pdf

Kuttner, K. N., \& Posen, A. S. (1999). Does talk matter after all? Inflation targeting and central bank behavior.' Federal Reserve Bank of New York Staff Report, 88. http://www.newyorkfed.org/research/staff_reports/sr88.pdf

Kydland, F. E., \& Prescott, E. C. (1977). Rules rather than discretion: The inconsistency of optimal plans. Journal of Political Economy, 85, 473-492. http://dx.doi.org/10.1086/260580

Lildholdt, P., \& Wetherilt, A. V. (2004). Anticipation of monetary policy in UK financial markets. Bank of England Working Paper, No 241. http://www.bankofengland.co.uk/publications/workingpapers/wp241.pdf

Mahadeva, L., \& Sterne, G. (2000). Monetary policy frameworks in a global context. Routledge, London.

Mishkin, F. S. (2004). Can central bank transparency go too far?. NBER Working Paper, No 10829.http://www.nber.org/papers/w10829.pdf

Mishkin, F. S., \& Schmidt-Hebbel, K. (2007). Does inflation targeting make a difference?' NBER Working Paper, No 12876. http://www0.gsb.columbia.edu/faculty/fmishkin/papers/nberwp.w12876.pdf

Polillo, S., \& Guillén, M. F. (2005). Globalization pressures and the state: The global spread of central bank independence. American Journal of Sociology, 110, 1764-1802. http://dx.doi.org/10.1086/428685 
Poole, W., \& Rasche, R. H. (2003). The impact of changes in FOMC disclosure practices on the transparency of monetary policy: Are markets and the FOMC better "synched"?. The Federal Reserve of St. Louis Review, 85(2), 1-10. http://research.stlouisfed.org/publications/review/03/01/PooleRasche.pdf

Poole, W., Rasche, R. H., \& Thornton, D. L. (2002). Market anticipations of monetary policy actions. The Federal $\begin{array}{llllll}\text { Reserve } & \text { St. Louis } & \text { Review, } & 84(4), & 65-94 .\end{array}$ http://research.stlouisfed.org/publications/review/02/07/65-94PooleRasche.pdf

Rafferty, M., \& Tomljanovich, M. (2002). Central bank transparency and market efficiency: An econometric analysis. Journal of Economics and Finance, 26, 150-161. http://dx.doi.org/10.1007/BF02755982

Rogoff, K. (1985). The optimal degree of commitment to a monetary target. Quarterly Journal of Economics, 100(4), 1169-90. http://dx.doi.org/10.2307/1885679

Sack, B., \& Wieland, V. (2000). Interest rate smoothing and optimal monetary policy: A review of recent evidence. Journal Economics and Business, 52, 205-228. http://dx.doi.org/10.1016/S0148-6195(99)00030-2

Siklos, P. (2002). The changing face of central banking: Evolutionary trends since world war II. New York: Cambridge University Press.

Siklos, P. L. (2003). Assessing the impact of changes in transparency and accountability at the bank of Canada. Canadian Public Policy - Analyse de Politiques, 29(3).

Siklos, P. L. (2004). Central bank behavior, the institutional framework, and policy regimes: Inflation versus non inflation targeting countries. Contemporary Economic Policy, 22(3), 331-343. http://dx.doi.org/10.1093/cep/byh024

Sterne, G., Stasavage, D., \& Chortareas, G. (2002). Does it pay to be transparent? International evidence from central bank forecasts. Federal Reserve Bank of St Louis Review, 84(4), 99-117. http://research.stlouisfed.org/publications/review/article/2333

Stiglitz, J. (1998). Central banking in a democratic society. De Economist, 146(2), 199-226. http://dx.doi.org/10.1023/A:1003272907007

Walsh, C. (2003). Monetary theory and policy. Second Edition. The MIT Press.

Walsh, C. E., (1999). Announcements, inflation targeting and central bank incentives. Economica, 66, 255-69. http://dx.doi.org/10.1111/1468-0335.00168

Woodford, M. (1999). Optimal monetary policy inertia. The Manchester School, 67, 1-35. http://dx.doi.org/10.1111/1467-9957.67.s1.1

\section{Notes}

Note 1. An overview of the theoretical and empirical cases for CBI can be found in Eijffinger and De Haan (1996), Cukierman (1998) and Kißmer and Wagner (1998).

Note 2. Cukierman et al., (1992), Eijffinger and de Haan (1996) and Walsh (2003, Chapter 8) provide an excellent summary of the empirical work.

Note 3. In their study on the effect of the transparency degree on the financial market variability, Geraats et al., (2006) notice that the variability of the interest rate and the variability of the transparency index can be very different. As a result, cross-section correlations between the (level or average of the) interest rate and transparency could be very misleading.

Note 4. These countries are listed in the Table 4 in the appendix.

Note 5. See Eijfinger and De Haan (1996), De Haan (1997) and de Haan et al., (2003) for a literature review.

Note 6. Dincer and Eichengreen used the methodology proposed by Eijffinger and Geraats,

Note 7. Bomfim and Rudebusch (2000) proposed also a method but less popular than Cukierman and Meltzer method.

Note 8. See Mishkin and Schmidt-Hebbel (2007) for the values of the inflation targets of the industrialized and emerging countries retained in this paper.

Note 9. Table 4 in Appendix displays the value of the credibility index for the countries retained in our study.

\section{APPENDIX}

In Cukierman and Meltzer's (1986) approach, the credibility index can be expressed as: 


$$
\text { Cre }=\left\{\begin{array}{cll}
1 & \text { if } & E\left(\pi_{t}\right) \leq \pi \\
1-\frac{\left(E\left(\pi_{t}\right)-\pi^{t}\right)}{0.2-\pi^{t}} & \text { if } & \pi^{t} \leq E\left(\pi_{t}\right) \leq 20 \\
0 & \text { if } & E\left(\pi_{t}\right) \geq 20
\end{array}\right.
$$

Some authors, as Cecchetti and Krause (2002), while using this approach, supposed the same level for the inflation target for all the countries they retained in their study. In addition, they also assume that the expected inflation used in order to construct the credibility index is based on the realized inflation of the previous period. Contrary to these authors, we fix the same inflation target for the industrialized countries and the same target for the emerging countries. For the industrialized countries, we suppose that the inflation target is 2.125 (Note 8), which corresponds to the average of the target fixed by some central bank of industrialized countries practicing inflation target. As for the emerging countries, we suppose that the inflation target is equal to 3.25. Furthermore, the expected inflation is obtained using data from Datastream (Note 9).

Table 1. The effects of central bank independence on macro-financial variables

\begin{tabular}{|c|c|c|c|c|}
\hline Dependent variables & constant & independence $_{t-1}$ & model type & test Haussman \\
\hline Observed inflation level & $\begin{array}{c}6.561^{* *} \\
(3.46)\end{array}$ & $\begin{array}{l}-3.169 \\
(-1.20)\end{array}$ & random effect & -3.71 \\
\hline Expected inflation level & $\begin{array}{l}2.518 \\
(1.60)\end{array}$ & $\begin{array}{l}-2.877 \\
(-1.15)\end{array}$ & random effect & -0.11 \\
\hline Observed inflation variation & $\begin{array}{l}-0.915 \\
(-0.95)\end{array}$ & $\begin{array}{l}-0.173 \\
(-0.09)\end{array}$ & random effect & -88.12 \\
\hline Expected inflation variation & $\begin{array}{l}-0.171 \\
(-0.30)\end{array}$ & $\begin{array}{l}0.009 \\
(0.01)\end{array}$ & random effect & -4.67 \\
\hline Observed GDP level & $\begin{array}{c}3.914 * * \\
(2.00)\end{array}$ & $\begin{array}{l}4.242 \\
(1.34)\end{array}$ & random effect & -4.28 \\
\hline Expected GDP level & $\begin{array}{c}5.792 * * \\
(2.78)\end{array}$ & $\begin{array}{l}4.273 \\
(1.32)\end{array}$ & random effect & -0.13 \\
\hline Observed GDP variation & $\begin{array}{l}-0.608 \\
(-0.92)\end{array}$ & $\begin{array}{l}1.685 \\
(1.19)\end{array}$ & random effect & 0.00 \\
\hline Expected GDP variation & $\begin{array}{l}-0.402 \\
(-0.50)\end{array}$ & $\begin{array}{l}-0.726 \\
(-0.47)\end{array}$ & random effect & -5.70 \\
\hline $10-y$ rate level & $\begin{array}{c}7.382 * * \\
(11.16)\end{array}$ & $\begin{array}{c}-3.710 * * \\
(-2.92)\end{array}$ & random effect & -241.27 \\
\hline 5-y rate level & $\begin{array}{c}8.212 * * \\
(12.52)\end{array}$ & $\begin{array}{c}-4.242 * * \\
(-3.69)\end{array}$ & random effect & -123.22 \\
\hline $10-y$ rate variation & $\begin{array}{c}0.683^{* *} \\
(8.02)\end{array}$ & $\begin{array}{c}-0.379 * * \\
(-2.23)\end{array}$ & random effect & -0.06 \\
\hline 5-y rate variation & $\begin{array}{c}0.792 * * \\
(8.51)\end{array}$ & $\begin{array}{c}-0.459 * * \\
(-2.45) \\
\end{array}$ & random effect & -0.13 \\
\hline
\end{tabular}

** and * indicate that the corresponding coefficient is statistically significant at the $5 \%$ and $10 \%$, respectively. 
Table 2. The effects of central bank transparency on macro-financial variables

\begin{tabular}{|c|c|c|c|c|}
\hline Dependent variables & constant & transparence $t_{t-1}$ & model type & test Haussman \\
\hline Observed inflation level & $\begin{array}{c}6.691 * * \\
(8.54)\end{array}$ & $\begin{array}{c}-6.889 * * \\
(-5.54)\end{array}$ & random effect & -415.98 \\
\hline Expected inflation level & $\begin{array}{c}8.032^{* *} \\
(6.54)\end{array}$ & $\begin{array}{c}-8.134 * * \\
(-4.61)\end{array}$ & random effect & -207.49 \\
\hline Observed inflation variation & $\begin{array}{l}-0.223 \\
(-0.33)\end{array}$ & $\begin{array}{l}0.359 \\
(0.32)\end{array}$ & random effect & -74.35 \\
\hline Expected inflation variation & $\begin{array}{l}-0.577 \\
(-0.66)\end{array}$ & $\begin{array}{l}0.832 \\
(0.58)\end{array}$ & random effect & -72.55 \\
\hline Observed GDP level & $\begin{array}{c}25.743 * * \\
(8.60)\end{array}$ & $\begin{array}{c}-32.674 * * \\
(-7.15)\end{array}$ & random effect & -55699.20 \\
\hline Expected GDP level & $\begin{array}{c}13.379^{* *} \\
(6.16)\end{array}$ & $\begin{array}{c}-13.164 * * \\
(-3.81)\end{array}$ & random effect & -6730.85 \\
\hline Observed GDP variation & $\begin{array}{l}-0.023 \\
(-0.01)\end{array}$ & $\begin{array}{l}-0.747 \\
(-0.27)\end{array}$ & random effect & -5620.79 \\
\hline Expected GDP variation & $\begin{array}{l}-0.791 \\
(-0.86)\end{array}$ & $\begin{array}{l}0.964 \\
(0.62)\end{array}$ & random effect & $1.46 \mathrm{E}-38$ \\
\hline $10-y$ rate level & & $\begin{array}{c}-9.574 * * \\
(-9.26)\end{array}$ & fixed effect & 8.98 \\
\hline 5-y rate level & $\begin{array}{c}10.119 * * \\
(10.21)\end{array}$ & $\begin{array}{c}-10.027 * * \\
(-7.77)\end{array}$ & random effect & -39.00 \\
\hline $10-y$ rate variation & $\begin{array}{c}0.224 * * \\
(6.61)\end{array}$ & $\begin{array}{l}0.016 \\
(0.30)\end{array}$ & random effect & $-5.53 \mathrm{E}-4$ \\
\hline 5-y rate variation & $\begin{array}{c}0.283 * * \\
(5.78)\end{array}$ & $\begin{array}{l}-0.009 \\
(-0.12)\end{array}$ & random effect & $-2.71 \mathrm{E}-3$ \\
\hline
\end{tabular}

** and * indicate that the corresponding coefficient is statistically significant at the $5 \%$ and $10 \%$, respectively.

Table 3. The effects of central bank credibility on macro-financial variables

\begin{tabular}{|l|c|c|l|c|}
\hline Dependent variables & constant & credibility t-1 $^{*}$ & model type & test Haussman \\
\hline Observed inflation level & $19.293^{* *}$ & $-14.639^{* *}$ & random effect & -2579.91 \\
Expected inflation level & $(4.78)$ & $(-3.41)$ & & \\
Observed inflation variation & $23.668^{* *}$ & $-21.748^{* *}$ & random effect & -7949.84 \\
Expected inflation variation & $(14.87)$ & $(-12.59)$ & & \\
& $-8.041^{* *}$ & $7.884^{* *}$ & random effect & -1058.09 \\
Observed GDP level & $(-6.61)$ & $(5.96)$ & & -174.26 \\
Expected GDP level & $-3.013^{* *}$ & $3.155^{* *}$ & random effect & \\
Observed GDP variation & $(-2.38)$ & $(2.31)$ & & 2061.20 \\
Expected GDP variation & & $-7.913^{* *}$ & fixed effect & -10084.15 \\
10-y rate & $(-3.06)$ & & \\
& $30.256^{* *}$ & $-24.490^{* *}$ & random effect & $2,00 \mathrm{E}-45$ \\
5-y rate & $(7.64)$ & $(-5.86)$ & & -2437.72 \\
10-y rate & -1.519 & 1.775 & random effect & \\
5-y rate & $(-1.12)$ & $(1.23)$ & & -3270.75 \\
& $-7.232^{* *}$ & $7.080^{* *}$ & random effect & \\
\hline
\end{tabular}

** and * indicate that the corresponding coefficient is statistically significant at the $5 \%$ and $10 \%$, respectively. 
Table 4. Central bank credibility index

\begin{tabular}{|l|l|l|l|l|l|l|l|l|}
\hline & $\mathbf{1 9 9 1}$ & $\mathbf{1 9 9 2}$ & $\mathbf{1 9 9 3}$ & $\mathbf{1 9 9 4}$ & $\mathbf{1 9 9 5}$ & $\mathbf{1 9 9 6}$ & $\mathbf{1 9 9 7}$ & $\mathbf{1 9 9 8}$ \\
\hline Australia & 0.99 & 1.00 & 1.00 & 1.00 & 0.92 & 1.00 & 1.00 & 1.00 \\
Austria & 0.97 & 0.94 & 0.95 & 0.97 & 1.00 & 1.00 & 1.00 & 1.00 \\
Belgium & 0.98 & 1.00 & 1.00 & 1.00 & 1.00 & 1.00 & 1.00 & 1.00 \\
Canada & 0.85 & 1.00 & 1.00 & 1.00 & 1.00 & 1.00 & 1.00 & 1.00 \\
Denmark & 1.00 & 1.00 & 1.00 & 1.00 & 1.00 & 1.00 & 1.00 & 1.00 \\
Espagne & 0.89 & 0.88 & 0.92 & 0.91 & 0.90 & 0.95 & 1.00 & 1.00 \\
Finlande & 0.92 & 0.98 & 1.00 & 1.00 & 1.00 & 1.00 & 1.00 & 1.00 \\
France & 0.97 & 1.00 & 1.00 & 1.00 & 1.00 & 1.00 & 1.00 & 1.00 \\
Germany & 0.89 & 0.89 & 0.91 & 0.98 & 1.00 & 1.00 & 1.00 & 1.00 \\
Greece & 0.67 & 0.68 & 0.66 & 0.72 & 0.76 & 0.76 & 0.86 & 0.88 \\
Hungary & 0.87 & 0.89 & 0.84 & 0.83 & 0.54 & 0.50 & 0.53 & 0.58 \\
Iceland & 0.84 & 0.95 & 0.94 & 1.00 & 1.00 & 1.00 & 1.00 & 1.00 \\
Ireland & 1.00 & 1.00 & 1.00 & 1.00 & 1.00 & 1.00 & 1.00 & 1.00 \\
Italy & 0.88 & 0.90 & 0.92 & 0.94 & 0.87 & 0.92 & 1.00 & 1.00 \\
Japon & 0.95 & 1.00 & 1.00 & 1.00 & 1.00 & 1.00 & 1.00 & 1.00 \\
Korea & 0.86 & 0.95 & 1.00 & 0.92 & 0.99 & 0.96 & 0.97 & 0.79 \\
Mexique & 0.33 & 0.47 & 0.67 & 0.78 & 0.00 & 0.00 & 0.00 & 0.00 \\
Netherland & 0.98 & 0.98 & 1.00 & 0.99 & 1.00 & 1.00 & 1.00 & 1.00 \\
New Zeland & 0.99 & 1.00 & 1.00 & 1.00 & 0.92 & 0.99 & 1.00 & 1.00 \\
Norway & 0.97 & 1.00 & 1.00 & 1.00 & 1.00 & 1.00 & 0.99 & 1.00 \\
Poland & 0.78 & 0.75 & 0.67 & 0.56 & 0.48 & 0.54 & 0.61 & 0.67 \\
Portugal & 0.76 & 0.76 & 0.84 & 0.88 & 0.92 & 0.97 & 1.00 & 0.98 \\
Sweden & 0.70 & 1.00 & 0.88 & 1.00 & 0.99 & 1.00 & 1.00 & 1.00 \\
Switzeland & 0.85 & 0.92 & 0.95 & 1.00 & 1.00 & 1.00 & 1.00 & 1.00 \\
USA & 0.94 & 0.99 & 0.98 & 1.00 & 0.99 & 0.97 & 1.00 & 1.00 \\
\hline
\end{tabular}

